\title{
Seeking Détente and Driving Integration: The European Community's opening towards the People's Republic of China, 1975-1978
}

\author{
Marie Julie CHENARD
}

On 4 May 1975 Sir Christopher Soames, Vice-President of the European Commission responsible for external relations, proposed in Beijing the establishment of official relations between the European Community (EC) and the People's Republic of China (PRC). ${ }^{1}$ Subsequently, on 15 September 1975, the PRC became the first Communist country besides Yugoslavia to accredit an Ambassador to the Community. Meanwhile, Soames also started discussions with the Chinese for a trade agreement. The negotiations resulted on 3 April 1978 in the signature of the EEC-PRC Trade Agreement which was the first the Community concluded with a Communist state based on the so-called Outline Agreement. ${ }^{2}$ This was the draft the Commission had forwarded to the state-trading countries in November 1974 to replace all national, bilateral agreements as a step towards the implementation of the common commercial policy. Meanwhile, despite American President Richard Nixon's visit to China in 1972, the United States (US) and the PRC did not establish diplomatic relations until 1979. Until then a US-China trade agreement proved unfeasible.

The few studies of Europe-China relations that tackle, even if only briefly, the European Community's opening to China in the 1970s, agree that a contextual link to the Cold War existed. ${ }^{3}$ However, most of the works are political-science based or journalistic, examining a longer time-span. A historical analysis of the beginning of the EC-PRC relationship based on multi-lateral and multi-archival evidence is missing. Above all, none of the studies investigate what exactly such a link meant for European integration, particularly the EC institutional framework.

Although building relations with the PRC was not a priority for the EC in the 1970s, due to China's political, economic and geographic distance, this gap in the literature is nonetheless significant: investigating the case of China develops recent scholarship which explores the intersection between European integration and the Cold War. Piers Ludlow's conclusion on the EC institutions and the East-West conflict, that "Fighting the Cold War and integrating Western Europe remained two distinct processes throughout the 1960s", does not apply to the Community's opening

1. CA [Churchill Archives Centre], Cambridge, United Kingdom, permission by Lady Soames, SOAM/ 42/1975/China, Banquet speech, Soames, 04.05.1975.

2. Official Journal of the EEC [OJ], L 123(1978), p.2.

3. See, for example, B. FINDORFF, China und die Europäische Gemeinschaft, in: Aussenpolitik, 11(1972); H. KAPUR, China and the European Economic Community, Martinus Nijhoff Publishers, Dordrecht, 1986; M. YAHUDA, The Sino-European Encounter, in: D. SHAMBAUGH et al., ChinaEurope Relations, Routledge, London, 2008, pp.14 and 24-25. 
to the PRC in the mid-1970s. ${ }^{4}$ Similarly, Takeshi Yamamoto's interpretation regarding the EC response to the Soviet Union, that after 1975 both Cold War and European integration history evolved separately, is not a valid one when looking at the Chinese case. $^{5}$

This analysis takes a Community-centred perspective, focusing on how the interests of the nine EC Member States (the Nine) and those of the EC intergovernmental and supranational actors came together in Brussels, Strasbourg and Luxembourg to shape the Community's policy towards China. The article seeks to explain how European integration and Cold War developments related in the EC's opening to the PRC. Of particular interest are the questions of why the EC chose to open diplomatic relations with China in 1975 and conclude a trade agreement in 1978, and who within the complex Community decision-making system was primarily responsible for these initiatives.

The study is based on recently released archival sources of the European Union, France, Germany, Britain, Soames's private papers, and interviews conducted with former EC officials. ${ }^{6}$ The article will focus its analysis on the significance of the EC's relationship to China first for the Community's external affairs, and second in respect of the Community's institutional decision-making. ${ }^{7}$

\section{Promoting European Détente}

Détente enabled the Community to develop its relationship with the PRC in the first place. After the American opening to China in 1972, all those West European governments which had not yet done so, normalised their diplomatic relations - therefore all the Member States apart from Denmark and France which had already esta-

4. N.P. LUDLOW, An Insulated Community?, in: N.P. LUDLOW, European Integration and the Cold War, Routledge, London, 2007, p.144.

5. T. YAMAMOTO, Détente or Integration?, in: Cold War History, 7/1(2007), p.89.

6. Council of Ministers Archive [CMA], Brussels, Belgium; European Commission's Historical Archives [ECHA], Brussels, Belgium; Historical Archives of the European Union [HAEU], Florence, Italy; The National Archives [NA], Kew, United Kingdom; Centre d'Accueil et de Recherche des Archives Nationales [CARAN], Paris, France; CAC [Centre des Archives Contemporaines], Fontainebleau, France; MAE [Archives du ministère des affaires étrangères], La Courneuve, France; Bundesarchiv [BA], Koblenz, Deutschland; Politisches Archiv des Auswärtigen Amts [PAAA], Berlin, Deutschland; interview with: Edmund Wellenstein, the former Commission Director General for External Relations, 06.01.2010; Lord Hannay of Chiswick, Soames's former chef de cabinet, 10.03.2010; David Ting, the former Commission Desk Officer for relations with Eastern Europe 01.04.2010; Théo Junker, former EP official at the General Directorate of Interparliamentary Commissions and Delegations, 08.06.2010; Louis Kawan, the former Commission Head of Unit overseeing relations with state trading countries, 12.06.2010; John Maslen, the former Commission China Desk Officer, 16.06.2010.

7. The author would like to thank Emily Gray, Eirini Kavamouzi, Piers Ludlow, Emmanuel MourlonDruol, Angela Romano, Johann Smula and Arne Westad for their help and advice on earlier drafts of this article. 
blished full diplomatic relations on ambassadorial level in 1950 and 1964 respectively, and Ireland which had recognised the PRC but only set up full diplomatic representation in $1979 .{ }^{8}$ Consequently, the Nine also accepted, in principle, that the EC should have official relations with the People's Republic. ${ }^{9}$

Seen in relation to superpower détente, that is the relaxation of East-West tension and creation of a bipolar international system managed by the United States and the Soviet Union, the EC-PRC connection meant strengthening the Community's capacity as "Third Force". ${ }^{10}$ This concept had different meanings at different times for different actors. ${ }^{11}$ Applied to the mid-1970s, "Third Force" would relate to the Community's aim of European détente, overcoming rather than consolidating the bipolar Cold War order, and of the Community's independence as an international actor in its own right. ${ }^{12}$ Indeed, Soames declared to his Chinese hosts on 4 May 1975 that:

"We do not believe that the world's problems can or should be resolved only by the action of the two superpowers, and we believe it important that Europe should speak with a single voice in its dealing with them". ${ }^{13}$

In reaction to Soames's visit, a German Member of the European Parliament (MEP), Christian-Democrat Hans Edgar Jahn, stated in a European Parliament (EP) debate on 18 June 1975 that the "Chinese policy-makers were quite clear-sighted and realistic about regarding the European Community as a third world power". ${ }^{14}$ Furthermore, at the European Council on 29 December 1975, Belgian Prime Minister Leo Tindemans recommended to his counterparts in his report for a European Union a concerted approach to China. The Heads of State and Government had instructed Tindemans in December 1974 to write such a report in which he was to investigate a definition for a "European Union". In the chapter dedicated to "Europe in the World" Tindemans advocated a common external policy to counter "our vulnerability and our relative impotence". ${ }^{15}$ Thus, a coordinated policy on China was to contribute to the independence of the Community. This fitted with the idea of Étienne Davignon, then Director General of the political department of the Belgian ministry of Foreign Affairs, in so far as he had suggested a concerted approach to the PRC as a matter for European Political Cooperation (EPC) to work out. ${ }^{16}$ EPC had aimed since 1970 to coordinate more closely the foreign policies of the Member States.

8. C. MACKERRAS, A. YORKE, The Cambridge Handbook of Contemporary China, Cambridge University Press, Cambridge, 1991, pp.151-155.

9. ECHA, BAC/136/1987/624, Note, 686 réunion, Meyer to Soames, Ortoli, 18.05.1973.

10. See, for example, W. LOTH, Overcoming the Cold War, Palgrave, New York, 2001, p.viii.

11. W. LIPGENS, W. LOTH, Documents on the History of European Integration, de Gruyter, Berlin, 1988, pp.4-8.

12. See, for example, A. ROMANO, Western Europe's self-assertion towards the superpowers: the CSCE chance and its aftermaths, in: A. DEIGHTON, G. BOSSUAT, The EC/EU: a world security actor?, Soleb, Paris, 2007, pp.152-169; A. VARSORI, Crisis and Stabilization in Southern Europe during the 1970s, in: Journal of European Integration History [JEIH], 1(2009), p.6.

13. CA, SOAM/42/1975/China, Banquet speech, Soames, 04.05.1975.

14. European Parliament Debates, 16 to 20 June 1975, in: OJ, C 192(1975).

15. Bulletin of the European Communities Supplement 1/76, pp.14 and 18.

16. NA, FCO30/1657, Davignon to Wright, 11.01.1973. 
Vis-à-vis the United States, the EC's dealings with China proved that Western Europe had more than merely the "regional interests" which American Secretary of State Henry Kissinger had ascribed to his allies in his "Year of Europe"-speech in April 1973, in contrast to American "global responsibilities" ${ }^{17}$ The US and the European Community entertained official relations, and the Commission had a diplomatic representation in Washington. In the 1970s the transatlantic relationship faced new strains mainly in the areas of economics and defence. ${ }^{18}$ In Beijing in May 1975, Soames commented sharply to the Chinese Foreign Minister Chiao Kuanhua on Kissinger's arrogance. ${ }^{19}$ In relation to the PRC, the Community could present itself as more skilful than the United States: the EC set up official relations which the Americans did only five years later in 1979; and contrary to the US, the Community made progress in negotiating a trade agreement, successfully concluding a deal before the Americans had even set up diplomatic relations with the PRC. When Commission President Roy Jenkins visited American President Jimmy Carter in April 1977, it was the Commission that set the agenda on China. During a lunch conversation with US Secretary of State Cyrus Vance on 18 April, Vance admitted that in contrast to the EC-China relationship the US-China one had reached a deadlock. ${ }^{20}$

As regards the Soviet Union, the idea of a "Third Force" also acquired new substance because links to the PRC reinforced the message that the Community was a political reality the Soviets would have to deal with sooner or later. The Community's contacts with China developed against the backdrop of the Sino-Soviet dispute, and the Soviet Union's refusal to recognise the European Community. ${ }^{21}$ Interestingly, Soames visited Beijing just before the Helsinki Summit of the Conference on Security and Cooperation in Europe (CSCE) in July 1975. At the CSCE a central objective of the Community was to gain Soviet recognition as a unified political actor. ${ }^{22}$ This is precisely what setting up official relations with the PRC proved. Indeed, a reason for engaging with China lay in geopolitics. ${ }^{23}$ The Commission's aim was to isolate the Soviet Union, leaving it as the only blank spot on the world map which had not yet engaged officially with the EC. The Community decision-makers regarded the EECPRC Trade Agreement not just as an economic, but more as a political precedent in the dealings with other Communist countries. The brief for the President of the

17. J. HANHIMÄKI, Searching for a Balance, in: N.P. LUDLOW, op.cit., pp.166-168.

18. See, for example, P. WINAND, 'Loaded words and disputed meanings: the Year of Europe speech and its genesis from an American perspective', in: J. VAN DER HARST, Beyond the Customs Union, Bruylant, Brussels, 2007, pp.297-315.

19. CA, SOAM/42/1975/China, Record, Meeting between Soames and Chiao, 05.05.1975.

20. HAEU, EN/1568, Summary of lunch conversation at the Department of State, Washington: 18 April, Tickell, 03.05.1977.

21. J. SPENCE, The Search for Modern China, WW. Norton\&Company, New York, 1999, pp.553559; T. YAMAMOTO, op.cit., pp.75-79.

22. A. ROMANO, From Détente in Europe to European Détente, PIE Peter Lang, Brussels, 2009, p. 81.

23. Personal notes based on interviews that are still in the process of transcription approval. See also, NA, FCO30/1282, Note, China and the Community, Tickell to Mason, 15.05.1972; NA, FCO40/460, note, The external relations of the European Community, Permanent Under-Secretary's Planning Committee, 22.03.1973. 
Council of Ministers' speech to the EP Political Affairs Committee on 14 March 1978 on the EEC-PRC Trade Agreement, for instance, recommended making this point, albeit cautiously. ${ }^{24}$

Thus, closer ties with the PRC supported the Community's endeavour to establish itself as a political actor in international affairs and be a Third Force. For the EC to set up diplomatic relations with the PRC meant not only to establish ties to a country with a permanent seat on the United Nations Security Council and significant links to the Third World - therefore with a country that played an increasingly relevant role in world politics. It also meant developing connections with a government that encouraged European integration as a counterweight to the power of the Unites States, and that shared with the Community a central geostrategic concern, the Soviet Union. It is worth however examining more closely the consequences of the EC China policy for the Community's relationship to the Eastern bloc and thereby illustrate the impact of European integration on the Cold War in Europe.

\section{Fostering Détente in Europe}

The Community's advances vis-à-vis Communist China provoked more contacts between the EC and the Soviet bloc. The Soviet Union had sought to control all relations by the East European countries with the Community through the Council of Mutual Economic Assistance (Comecon), rather than allowing individual, bilateral ties. In the 1970s however the Soviet Union had increased difficulties in checking the East European states. Romania for example had already developed informal contacts with the Community; Hungary also sought to discard the official policy of nonrecognition of the EC; Czechoslovakia and Poland circumvented Comecon rules to export agricultural and manufactured goods to the Community. ${ }^{25}$ As a consequence of Soames's China initiative in 1975, East European officials asked the Commission directly about the EC's objectives concerning the PRC. ${ }^{26}$ Although these contacts remained unofficial, the Commission succeeded in meeting the representatives not simply in restaurants, as had previously been the case, but directly at the Berlaymont, the headquarters of the Commission in Brussels - a change which underlined the Commission's increased stature. A further example is the contact by the editor of the East-West Journal, Jan Zoubek, who voiced the East European concerns to Friedrich Klein, Director at the Commission's Directorate General for External Relations in charge of relations with the state-trading countries. ${ }^{27}$

24. CMA, IA/19648/1978, Speech, EEC-China Trade Agreement, 09.03.1978.

25. See, for example, S. KANSIKAS, The CMEA and the EC challenge, 1969-1976, PhD thesis, University of Helsinki, May 2011.

26. HAEU, EN/1987, Note, Contact avec diplomates de pays de l'Est, Stefani to Meyer, 06.06.1975.

27. ECHA, BAC/136/1987/624, Zoubek to Klein, 06.05.1975. 
The Soviet government for its part expressed its misgivings on the EC-PRC rapprochement. When for the first time a Soviet embassy representative, E. Plakhotnyi, visited the Commission, he discussed the EC-PRC relationship. On 20 February 1978: Plakothnyi stressed to Umberto Stefani, First Counsellor of the Commission's Secretariat General, that as his government had feared, the Commission had given the EEC-PRC Trade Agreement a particular political significance. ${ }^{28} \mathrm{He}$ meant to criticise the way the Commission had upheld the agreement as the first the Community had concluded with a Communist country. The Commission therefore appeared to play upon the Sino-Soviet rivalry to pressure the Soviets to follow the Chinese example to the EC's advantage.

Finally, the parallel improvement of the Community's relationship with the PRC and that with Comecon seems more than a simple coincidence. On 16 February 1976, just as exploratory talks for the EEC-PRC Trade Agreement were to begin, Gerhard Weiss, rotating Chairman of the Comecon Executive Committee, proposed an agreement with the EC. ${ }^{29}$ Next, with the momentum in the EEC-PRC trade negotiations taking off again in February 1977, Comecon accepted what it had previously opposed: direct negotiations with the Commission rather than only with the Council of Ministers. This was significant because it meant Comecon implicitly recognised the competencies of the Commission as a supranational institution speaking for the European Community. Again, just before the EEC-PRC Trade Agreement entered into force, Nicolai Fadeyev, then Comecon Secretary-General, welcomed a Community delegation in Moscow. Both sides issued a joint memorandum in which they agreed a number of principles for future contacts between the EC and Comecon, and reiterated the wish to set up diplomatic relations. ${ }^{30}$

It is true that the Nine judged that the primary reasons for Comecon's new approaches lay in Soviet domestic politics. Comecon's proposal of February 1976 came, amongst other matters, in the light of the impending Congress of the Communist Party of the Soviet Union. Leonid Brezhnev, General Secretary of the Communist Party of the Soviet Union presiding over the country, might want to use such a proposal to present the Soviet Union as progressive and ready for compromise. ${ }^{31}$ But a further factor, the Member States and the Commission believed, was Comecon's alarm over the PRC's improving ties with the Community. ${ }^{32}$

On that account, the EC's official relations and the trade agreement with the PRC led to more contacts between the Community and individual Eastern European countries, the Soviet Union, and - at least in the opinion of the Member States and the

28. HAEU, EN/1990, Note, Visite de Plakhotnyi, Stefani to Noël, Brussels, 20.02.1978.

29. Ninth General Report on the Activities of the European Communities in 1975, Brussels, pp.273274.

30. Thirteenth General Report on the Activities of the European Communities in 1978, Brussels, 1979, p.301.

31. NA, FCO/98/131, Telegram, Groupe d'experts Europe de l'Est, Lux Coreu to all Coreu, 15.04.1976.

32. See, for example, PAAA, B201/483, Note, Beziehungen EG zum RGW und den RGW-Staaten, 04.09.1975; NA, FCO/98/299, Telegram, Committee of Permanent Representatives 3 March, Maitland to FCO, 31.03.1977. 
Community officials - with Comecon. In this regard, the EC's opening to China contributed to détente in Europe because it provoked quantitatively and qualitatively new exchanges between the two sides of the iron curtain.

But in the case of the PRC, the effect of détente was not simply for the Community as a whole to define what role to play in international relations. More important, it brought to surface the need to clarify institutional competencies within the EC in order to play such a role. The next part of this article thus looks at the consequences of the opening of China for the Community's decision-making process.

\section{Deepening European Integration}

The impact of the Cold War on European integration is reflected in the issues and the institutional mechanisms through which the Nine coordinated their policies on China. One topic that all the Member States discussed with their Chinese counterparts was détente. As a consequence, the Nine sought to coordinate their views on it. ${ }^{33}$ In order to attune their views, the Nine had to decide which instruments to choose thus deepening European integration. Political coordination à Neuf in respect to China however took place mainly outside the legal framework of the Rome Treaties, namely at the EPC. The British had been the ones to push China onto the agenda of EPC in 1973. ${ }^{34}$ Resulting from the meeting at the EPC Asia Group on 4 February 1976, the Nine approved a common response to the Chinese regarding the Nine's attitude towards détente. Such a response noted that no alternative to détente existed, that the Nine and the Soviets had a different conception of détente, and that the Europeans had sufficient experience to nurture no illusions about Soviet intentions. Hence, it was at EPC where the Nine agreed that to develop individually their relations with China, one aspect on which they had to concert was how to counter Chinese criticism of their dealings with the Soviet Union. At those EPC meetings, the UK regarded the Commission's participation as important. This stance reflects the British view of the separation between the Community and EPC dealings as artificial and inefficient. The French vehemently opposed this conception of institutional arrangements. ${ }^{35}$

The work of the European Parliament (EP) also reveals a deepening of integration due to the rapprochement with China and the effects of the East-West conflict. Since its creation, the European Parliament had sought to raise its political profile and institutional standing. ${ }^{36}$ To this end it exploited the emerging relationship with China. After successfully pushing for a share in legislative and budgetary powers with the

33. NA, FCO/21/1391, Coordinated Policies towards China: Détente, Campbell, 26.11.1975.

34. MAE, DE-CE/1967-1975/1070, Telegram, Relations Chine-CEE, Beaumarchais to Diplomatie, 23.01.1973; MAE, DE-CE/1967-1975/1070, Telegram, Coopération politique à neuf - Chine et URSS, Beaumarchais to Diplomatie, 23.01.1973.

35. See, for example, MAE, DE-CE/4199, Telegram, Groupe d'experts Asie, Paris Coreu to London Coreu, 11.02.1977; MAE, DE-CE/4199, Cooperation politique des Neuf, Groupe Asie, 09.06.1977.

36. D. DINAN, Ever Closer Union, Palgrave Macmillan, Basingstoke, 2005, pp.259-280. 
Council of Ministers, the EP also obtained in the 1970s the right to inquire about the foreign policy issues that EPC dealt with. Furthermore, it instituted the mechanism of Question Time in parliamentary sittings during which MEPs held the Commission and the Council of Ministers directly accountable - even if still without the powers to depose them altogether. ${ }^{37}$ Interestingly, on the first occasion when the European Parliament used this mechanism in February 1973, it addressed the EC-PRC relationship. ${ }^{38}$

The European Parliament had long pressured the Commission and the Council of Ministers to establish official and wide-ranging links with the People's Republic. ${ }^{39}$ After Soames's visit to Beijing in 1975, the EP asked the Vice-President to explain the state of the Community's relations with the PRC. In particular, MEPs enquired about the consequences for the Community's relationship with the Soviet Union. ${ }^{40}$ Thereafter, at all the key moments when the Commission and the Council of Ministers decided on the next steps for the EEC-PRC Trade Agreement, MEPs from across the political spectrum showed little reticence in publicly outlining their views.

Their actions in the form of letters to the Commission, publications, written and oral questions, debates and resolutions, reveal how MEPs understood the EP's political role, and how they sought to realise it. For instance, when a Commission delegation headed to China for trade talks in July 1977, Lucien Radoux, a Belgian member of the Socialist Group, protested on 5 July about the postponement of the debate on a report on EC-China economic relations: "If Parliament wants to play its proper role, then it should be examining this report today". ${ }^{41}$ Consequently, the MEPs discussed and adopted a resolution. They advocated an arrangement beyond the classic trade agreement which the Council of Ministers and the Commission had opted for. The aim instead was to work towards a comprehensive economic agreement. Although this resolution may have had little effect, confirming the EP's limited influence, it did contribute to the EP's visibility.

The European Parliament also used relations with China to implement Community procedures adopted for trade agreements, the so-called Luns-Westerterp procedure. The Council of Ministers had to inform the EP of all decisive steps during the negotiations and only once the EP had ratified the trade agreement could it enter into force. ${ }^{42}$ In addition, when the EP debated the trade agreement on 11 April 1978, Lord Frederick Bessborough requested Wilhelm Haferkamp, Soames's successor as VicePresident of the Commission responsible for external affairs, to explain the material criteria by which the Commission would judge the effectiveness of the trade agreement. ${ }^{43}$

37. EUROPEAN PARLIAMENT, Rules of Procedure, Rule 47, 07.1976 and 12.1972.

38. HAEU, CPPE/642, Session Luxembourg, 02.1973.

39. See, for example, Written Question 243/71, OJ C 5(1972).

40. European Parliament Debates, 18 June 1975, OJC 192(1975).

41. The EP eventually examined the report: European Parliament Debates, 5 July 1977, OJC 183(1977).

42. CMA, IA/19649/1978, Hommel to Colombo, 03. and 09.03.1978; OJ L 123 (1978).

43. Oral Question 27/78, OJ 1229(1978). 
The EP's continuous pressure on China issues thus obliged the Council of Ministers and the Commission to assume public responsibility, and communicate regularly and publicly about their dealings with the PRC. In other words, détente and the EC's opening to China enabled the European Parliament to assume a greater role within the Community. This in turn furthered the institutional interaction. Yet, the Parliament was not the only entity to use China to raise its profile within the decisionmaking process. The Commission did so too.

Détente enabled the Commission to take the lead in the relationship with the PRC in the name of the Community. Although the Treaties of Rome left the institutional competencies in the conduct of foreign affairs open to interpretation, the Council of Ministers' determination to affirm its primacy in this area quickly became apparent. Never, according to the Council of Ministers, could the Commission act on its own initiative on commercial and tariff agreements, accession and association agreements, action in the international economic organisation, the common commercial policy, legation rights and the representation of the Community in external relations. The Commission by contrast claimed to hold general competence in negotiating with third countries based on Article 228 of the Treaty of Rome. ${ }^{44}$

The particular manner and timing in which the EC opened up to the PRC is an example of how the Commission's own institutional interest influenced the overall Community policy agenda in external relations. ${ }^{45}$ Soames resorted to a series of secret, unofficial talks with the Chinese Ambassador to Belgium, Li Lienpi, to organise his visit to Beijing in May 1975 which aimed at establishing official relations. ${ }^{46}$ Only on 19 March 1975, i.e. after Soames had accepted the invitation to China, did he inform the Committee of Permanent Representatives (Coreper) - the crucial committee of Ambassadors from the Member States to the EC which prepared all Council of Ministers decisions - about his dealing with the Chinese. ${ }^{47}$ In effect Soames confronted the Nine with a fait accompli.

During the EEC-PRC trade negotiations the Commission also persisted in asserting its role vis-à-vis the Nine. The way it ensured maximum room for manoeuvre in relation to the Member States is shown for instance by its forwarding of only the outline of the clauses of the trade agreement rather than a full draft until the Council of Ministers had approved its negotiating mandate. ${ }^{48}$ Moreover, the Commission succeeded in having its work accepted by the Council of Ministers without major interference: the Member States agreed to the Commission's working documents in the exploratory phase, its recommendation for the negotiating directives, and its initialled draft agreement without major changes.

44. E. CALANDRI, La CEE et les relations extérieures 1958-1960, in: A. VARSORI (ed.), Inside the European Community, Nomos, Baden-Baden, 2006, pp.421-422.

45. In response to F. GUIRAO, Solving the Paradoxes of Enlargement, in: JEIH, 2(2005).

46. Personal notes based on interviews.

47. ECHA, BAC/259.80, Minutes, $332^{\text {th }}$ meeting of the Commission, 09.04.1975.

48. ECHA, BAC/48/1984/687, Note, Chine, Denman to Haferkamp, 18.11.1977. 
Such a smooth and quick authorisation was not self-evident. The example of Yugoslavia, by contrast, shows that the Council of Ministers delayed time and again in 1978 the mandate for the Commission to negotiate a trade agreement. ${ }^{49}$ The permissive attitude over China is also noteworthy in a period when the Member States circumvented the Commission's competence on the common commercial policy. The Nine engaged for example in illegal trade negotiations with Japan and Eastern Europe. For instance, the UK negotiated bilaterally export restraint measures for footwear and textiles from Eastern Europe, and Benelux pressed Japan to continue export restraint on electronic items. Such actions were exclusive to the Community competencies and therefore for the Commission to handle. Consequently the Commission repeatedly complained that it could not "ignore such flagrant breaches of the Treaty without losing its credibility both with Member States and with third countries". ${ }^{50}$ These examples also suggest that the commercial aspects of the EC-PRC relationship mattered less to the Member States than was the case with links to other countries.

Once the EEC-PRC Trade Agreement had been signed, Haferkamp ensured the implementation of the deal through activist diplomacy. In September 1978, he led a Commission delegation including European industrialists to visit China. Against general expectations, he had an extended meeting with Hua Guofeng, PRC President and Chairman of the Chinese Communist Party. He thus succeeded in meeting Chinese leaders of the highest political rank. Haferkamp reported to the Council of Ministers:

"Not only was there a strong Chinese willingness to develop their relations with us. But we went with the right people and at the right time. Thus we showed our colleagues in the private sector in particular - and I hope member governments - that the Commission can perform a valuable role in circumstances such as this". 51

In February 1979, Jenkins too visited China, and stressed that "the essential purpose of his mission was to advance the implementation of the 1978 trade agreement". 52 Therefore, through the relationship with China Haferkamp and Jenkins could underline vis-à-vis the Member States the Commission's role and ability in the conduct of the Community's external relations.

Two important reasons allowed the Commission to take the lead regarding China. First, almost uniquely in the history of the Community's external relations, the Member States and the Community as such had to establish diplomatic and economic links from scratch. This was because at the end of the Chinese Cultural Revolution in 1969, none of the Member States had yet set up significant bilateral links with the PRC. Secondly, the Member States, working through the Council of Ministers, Coreper

49. HAEU, EN/1092, Tickell to Froschmaier, Brussels, 18.12.1978.

50. ECHA, BAC/3/1978/1517, Note, Illegal Negotiations by Member States, Hijzen to Soames, 07.06.1976.

51. BA, B136/16619, Note, Visit of European Community delegation to China September 24 - October 2, 1978, Haferkamp, Brussels, 09.10.1978.

52. ECHA, BAC/379/1991/77, Record of conversation between the President of the European Commission and the Minister of Foreign Trade of China, Beijing, 23 February 1979, Reuter, 05.031979. 
and EPC, adopted a "hands-off"-approach. The Member States gave the Commission room for manoeuvre in establishing diplomatic relations and negotiating the trade agreement.

The lack of involvement by the Nine may be explained by several factors. Above all, their attention simply lay elsewhere. More pressing internal issues were on the agenda such as the economic and financial crisis in Europe. Regarding foreign affairs, relations with Greece, Portugal, Spain, the developing countries and Eastern Europe took priority. ${ }^{53}$ The Member States also may have seen an advantage in letting the Commission have a go at forging closer relations with China without the risk of the Member States being blamed in the event of failure. Were the Commission successful however, the Nine seemed confident in their control over the Commission. In any case, official relations and the Commission's trade talks did not prevent the Member States from pursuing their individual commercial activities. They continued for example to sign agreements, establish mixed committees and organise trade fairs. Moreover, Community channels could provide an advantageous additional vehicle to complement the Nine's national policies, which the governments had not yet been able to develop very far. Lastly, the content of any Community policy towards China was more about symbolism than tangible results. Haferkamp's assessment of his visit to China in September 1978 epitomises the beginning of the EC's relationship with the PRC: "On doit souligner une nouvelle fois qu'il s'agit essentiellement d'une mission de prestige". 54

The role of the European Council in the Community's opening to China shows a further facet of how the Cold War and European integration intersected. The European Council was the legally non-binding body which institutionalised the summit meetings of the Heads of State and Government in December 1974. ${ }^{55}$ It was Soames who suggested at the EPC ministerial meeting on 26 May 1975 that the European Council answered positively to the Chinese at its meeting in July. ${ }^{56} \mathrm{~A}$ statement by the European Council would not only demonstrate in public the Community's commitment to the PRC, but it would also offer a counterweight to its declarations on détente linked to the CSCE which contained important concessions to the Soviet Union.

The adverse British reaction to Soames's suggestion reflects the care given to what the European Council ought to deal with, and the risks for détente the Foreign and Commonwealth Office (FCO) continued to see in any improvement in the EC-PRC relationship. The FCO briefed on 10 July 1975 that "On balance we are against this proposal". First, it "could create an undesirable precedent. The Community has

53. See Eighth to Twelfth General Report on the Activities of the European Communities, Chapters: External Relations, Brussels, 1975-1979.

54. ECHA, BAC/379/1991/86, Note, Préparation du voyage en Chine, Kawan to Beck, Brussels, 13.07.1978.

55. See E. MOURLON-DRUOL, Filling the EEC leadership vacuum? The creation of the European Council in 1974, in: Cold War History, 3(2010), 315-339.

56. MAE, DE-CE/1967-1975/1070, Telegram, Conseil du 26 mai, Cazimajou à Diplomatie Paris, 27.05.1975. 
opened relations with many other countries with much less fuss". Usually other states approached the Commission to set up official relations with the EC followed by a rather unceremonious procedure. Second, the European Council already planned a statement on détente, and "Too many declarations devalue the currency". Third,

"the disadvantages of possibly provoking them [the Soviets] further with a statement concerning relations with China will not be balanced by the advantages to be gained". ${ }^{57}$

But upon instruction of Foreign Secretary James Callaghan, the British delegation eventually accepted Soames's proposal. ${ }^{58}$ Since in the end none of the Nine disapproved, the Foreign Ministers agreed on 15 July 1975 without discussion that the European Council was to adopt Soames's statement. The European Council too consented without further deliberation.

Therefore a link between the Cold War and European integration consisted in how the Commission used China to justify a particular role of the European Council, and how in particular the FCO reacted to this. Moreover, the relationship to the PRC turned into a topic which contributed to legitimise the European Council's part in the integration process.

The idea of European détente as encapsulated in the CSCE relates, at least in hindsight, to specific features in the tone, style and substance of the Commission's engagement with China. At the signature ceremony of the trade agreement on 3 April 1978, for instance, Haferkamp emphasised its political dimension. The agreement reflected not just China's support of the political project of the Community. It also represented a symbol of trust between the two parties crucial to overcome the economic and political tensions in the current international climate. When Haferkamp stated that the agreement was not directed against anyone, the implicit target - the Soviet Union - was obvious. ${ }^{59}$

Remarkably, the Commission took the lead in implementing in relation to China what the Community had put down in the Second Basket of the Helsinki Final Act concerning economic relations between Eastern and Western Europe. Ideological differences were not to hinder the evolution of economic relations. Moreover, based on contextual evidence, the Commission effectively enacted in relation to the PRC the aims of the Third Basket which dealt with humanitarian issues. At the CSCE, EPC was exclusively responsible for this policy area ${ }^{60}$ But regarding China, the Commission upheld its role on humanitarian matters too. In the trade discussions with the Chinese it pushed successfully for a clause on more human contacts, and it insisted on including concrete measures such as exchange of visits, trade fairs and exhibitions. ${ }^{61}$ Therefore, the Commission put into practice some of the Community's aims

57. NA, FCO/30/2589, Brief, EEC/China, 10.07.1975.

58. NA, FCO/21/1391, Telegram, EEC-China: Fenn's letter to March 6/8 of 2 July, Callaghan, 14.07.1975.

59. ECHA, BAC/48/1984/687, Speech, Haferkamp, Brussels, 03.04.1978.

60. A. ROMANO, From Détente ..., p.45 and 159.

61. ECHA, BAC/136/1987/624, Fourth Meeting with Representatives of the Chinese Mission, 21.02.1976. 
for détente in Europe in respect to détente in international relations as a whole. How intentional this was is still open to debate.

The Commission, the European Parliament, and the European Council shaped the Community's response to China operating under different conditions. For the European Council China became a topic that contributed in legitimising its new role in the European integration process, a role for which it did not yet have a legal basis. The EP sought to create a new function for itself which the Rome Treaties had not elaborated upon. The Commission used China to reassert a role which arguably these treaties had already conferred but which the Member States contested.

Thus, while Francis Snyder states in his legal study on the European Union and China between 1949 and 2009 that the Cold War "provided the context for the establishment of diplomatic relations between the EEC and China", archival research suggests that the Cold War was much more than simply a context, a background canvas, a set of circumstances surrounding the relationship. ${ }^{62}$ It was not just EPC that viewed its task as being to shape the foreign policy activity of the European Community, and foster European détente. The European Council, the European Parliament, and the Commission also sought to contribute.

\section{Conclusion}

The examination of the Community's dealings with the PRC between 1975 and 1978 reveals that the Cold War and European integration did not evolve separately, but intersected. This can be seen in three main ways: first, the relaxation of tensions between the United States and the Soviet Union enabled greater Community action in international politics, and the Community generated a European détente; conversely, the extension of the Community's foreign policy activity furthered détente in Europe; finally, individual EC institutions capitalized on détente by asserting their own role in EC decision-making.

To begin with, the relaxation of East-West tensions, particularly Nixon's opening to China, made it possible for the Community to establish official relations with the PRC. At the same time, the EC's opening to China illustrates how the Community sought to establish itself politically vis-à-vis the two superpowers. As a "Third Force", it positioned itself against the United States as a unified actor which pursued global and not merely regional interests; indeed, the EC proved more adroit than the Americans in forging links to the PRC in the mid-1970s. In relation to the Soviet Union, both the EEC-PRC diplomatic relations and the trade agreement set political precedents for the Community's interaction with the other Communist countries. It was the Commission rather than the Member States working individually, through EPC or the Council of Ministers that spoke for the Community.

62. F. SNYDER, The European Union and China, 1949-2009, Oxford/Portland, Oregon, 2009, p.45. 
The impact of furthering European integration, that is extending EC foreign policy activity to China, also contributed to driving détente in Europe. Decision-makers in the Community interpreted Comecon's new approaches to the EC, which coincided with the burgeoning EC-PRC relationship, as partly motivated by Soviet fears of losing out against China, and losing control over Eastern European bilateral dealings with the EC. The EC-PRC relationship featured prominently on the agenda of the increasing contacts between the Commission and individual Eastern European and the Soviet representatives.

Finally, the EC's response to the People's Republic reveals the impact of the Cold War on the bureaucratic politics of the Community. Seeking European détente beyond Europe allowed the European Parliament and above all the Commission to assert their influence against EPC and the Council of Ministers in defining the future role of the Community in external relations, how was this role to be carried out, and who should speak to the PRC on behalf of the EC - in other words, deepening integration. In the final analysis, Soames was primarily responsible for the China policy initiative. The main factor behind his decisions was inter-institutional jockeying for power. The broader implication of this research is that the wrangle for competencies within the EC institutional system intertwined with broader trends of international history such as the end of the PRC's isolation from international events and détente. 